Vol 1. No. 4, Oktober 2021 P-ISSN : 2774-8014, e-ISSN : 2774-7034

\title{
PENINGKATAN HASIL BELAJAR SISWA MELALUI PENGGUNAAN MODEL MAKE A MATCH MATERI MENGENAL MALAIKAT ALLAH DAN TUGASNYA KELAS IV SDN MUKA SUNGAI KURUK SERUWAY
}

\author{
SAMSUL BAHRI \\ SDN Muka Sungai Kuruk \\ Email : samsulacehtamiang@gmail.com
}

\begin{abstract}
ABSTRAK
Penelitian ini bertujuan untuk mengetahui peningkatkan hasil belajar Pendidikan Agama Islam pada materi Mengenal Malaikat Allah dan Tugasnya bagi siswa kelas IV SD Negeri Muka Sungai Kuruk Kecamatan Seruway melalui penggunaan model make a match (mencari pasangan). Prosedur penelitian yang dilaksanakan peneliti dengan menggunakan jenis penelitian tindakan kelas (action research). Jenis penelitian tindakan kelas ini dirancang dalam dua siklus. Siklus I merupakan tindakan melalui model make a match (mencari pasangan). Pada siklus II merupakan perbaikan pembelajaran melalui model make a match (mencari pasangan) untuk meningkatkan hasil belajar dan meningkatkan aktivitas belajar siswa (activ learning). Data-data yang diperoleh setelah pelaksanaan tindakan selanjutnya dianalisis dengan analisis deskripsi komparatif. Dari hasil analis didapatkan bahwa hasil belajar siswa mengalami peningkatan yaitu pada siklus I siswa yang tuntas sebesar 63,33\% menjadi 90,00\% pada siklus II dari jumlah siswa 30 orang. Rata-rata hasil tes belajar pada siklus I dari 72,67 menjadi 87,00 pada siklus II. Sedangkan keaktifan belajar siswa meningkat yaitu pada siklus I siswa yang aktif sebesar $60.00 \%$ atau sebanyak 18 orang, menjadi $86.67 \%$ atau sebanyak 26 orang pada siklus II. Kesimpulan dari penelitian ini adalah model make a match (mencari pasangan) dapat meningkatkan hasil belajar siswa dan dapat berpengaruh positif terhadap aktifitas belajar siswa bagi kelas IV SD Negeri Muka Sungai Kuruk Kecamatan Seruway tahun pelajaran 2018-2019, serta model pembelajaran ini dapat digunakan sebagai salah satu alternatif pembelajaran Pendidikan Agama Islam.
\end{abstract}

Kata Kunci: Hasil Belajar, Model Make a Match

\section{PENDAHULUAN}

Pendidikan merupakan hal penting yang diperlukan bagi setiap manusia untuk memperoleh pengetahuan, wawasan serta meningkatkan martabat dalam kehidupan. Manusia berhak mendapatkan pendidikan yang layak sesuai perkembangannya. Pendidikan ini diperoleh melalui proses dari pendidikan dasar, menengah, sampai perguruan tinggi. Pengetahuan yang diperoleh melalui pendidikan akan sangat berguna bagi kehidupan akan datang manakala setiap orang mampu memanfaatkan dan mengoptimalkan pendidikan didapatnya selama ini. Manusia harus memahami bahwa pendidikan yang didapatnya selama ini bukan hanya sekadar formalitas belaka. Namun lebih dari itu, pendidikan akan sangat menentukan kehidupan berbangsa dan bernegara yang sejatinya dipupuk dari tingkat dasar.

Pendididikan Agama Islam yaitu pendidikan yang berdasarkan pokokpokok dan kajiankajian asas, yang meliputi ayat-ayat Al-Qur'an, hadist, dan kaidah-kaidah ketuhanan, muamalat, urusan pribadi manusia, asusila dan ajaran akhlak. Pendidikan Islam adalah bimbingan jasmani dan rohani berdasarkan hokum-hukum agama Islam menuju kepada terbentuknya kepribadian utama menurut ukuran-ukuran Islam.

Pendidikan layak diberikan secara optimal, khususnya pada siswa Sekolah Dasar. Pengetahuan diberikan di Sekolah Dasar merupakan pengetahuan dasar siswa yang berguna untuk melanjutkan kejenjang lebih tinggi. Peran aktif siswa sangat dibutuhkan dalam semua mata pelajaran termasuk dalam mata pelajaran Pendidikan Agama Islam. Dalam prakteknya pembelajaran Agama Islam yang terjadi di sekolah-sekolah saat ini lebih menekankan pada metode mengajar secara informatif yaitu guru menjelaskan atau ceramah dan siswa mendengarkan atau mencatat. Metode ceramah merupakan metode yang boleh dikatakan 
metode tradisional, karena sejak dulu metode ini telah dipergunakan sebagai alat komunikasi lisan antara guru dan siswa dalam proses belajar mengajar, (Syaiful Bahri Djamarah, 2006: 97).

Pembelajaran dengan metode ceramah merupakan yang paling disenangi oleh guru karena metode ini paling mudah dilaksanakan. Komunikasi yang terjadi dalam proses ini umumnya satu arah yaitu dari guru kepada siswa sehingga pembelajaran terpusat pada apa yang disampaikan oleh guru (teacher centered).

Pembelajaran di sekolah-sekolah juga cenderung hanya menekankan pada kemampuan intelektual dan kurang menekankan segi yang lain. Satu cara yang diterapkan untuk meningkatkan hasil belajar siswa selama di kelas adalah penerapan model pembelajaran dalam proses belajar mengajar. Model pembelajaran adalah pola yang digunakan sebagai pedoman dalam merencanakan pembelajaran di kelas.

Menurut Syaifurahman dan Ujiati, (2013:61), Pembelajaran yang kita laksanakan di kelas-kelas dengan metode belajar yang sama dari hari ke hari, maka kondisi tersebut sangat tidak menguntungkan baik bagi guru maupun siswa. Model pembelajaran yang berpusat pada siswa (student centered) yang dimaksud adalah model pembelajaran kooperatif (cooperative learning). Pembelajaran kooperatif adalah pendekatan pembelajaran yang berfokus pada penggunaan kelas kecil siswa untuk bekerja sama dalam memaksimalkan kondisi belajar untuk mencapai tujuan belajar (Sugiyanto, 2010:37). Model adalah pola atau bentuk yang dijadikan sebagai ancaman pelaksanaan. Menurut Kemp dalam Rusman model pembelajaran adalah suatu kegiatan pembelajaran yang harus dikerjakan guru dan siswa agar tujuan pembelajaran dapat dicapai efektif dan efisien. Dalam proses belajar mengajar tidak semua peserta didik dapat menangkap seluruh apa yang dijelaskan oleh guru, oleh sebab itu prestasi belajar peserta didik juga akan berbeda-beda. Banyak sekali faktor-faktor yang dapat mempengaruhi pencapaian hasil belajar atau prestasi belajar. Orangtua pun perlu untuk mengetahui apa saja faktor yang dapat mempengaruhi proses belajar pada anak mereka, sehingga orangtua dapat mengenali penyebab dan pendukung anak dalam berprestasi.

Menurut Komsiyah (2012:21) mengungkapkan bahwa dalam proses pembelajaran siswa kurang didorong untuk mengembangkan kemampuan berpikirnya. Proses pembelajaran di kelas cenderung diarahkan kepada kemampuan siswa untuk menghafal informasi, otak anak dipaksa untuk mengingat dan menimbun berbagai informasi tanpa dituntut untuk menghubungkan dengan kehidupan sehari-hari.

Dengan model pembelajaran guru akan dapat mengembangkan keterampilan intelektual, sosial, dan personal siswa. Pembelajaran yang melibatkan siswa akan menjadikan pembelajaran lebih bermakna sehingga diharapkan materi dapat tersampaikan dengan maksimal.

Model pembelajaran terdapat beberapa macam, salah satu model tersebut adalah Make a Match. Dengan menggunakan Make a Match siswa diajak untuk belajar sambil bermain, dengan cara saling mencocokkan kartu yang dimilikinya sehingga pembelajaran Agama Islam menjadi lebih menarik dan siswa dapat menyukai pembelajaran Agama Islam serta dapat dengan mudah memahami isi materi di sampaikan oleh guru sehingga hasil belajar siswa akan meningkat.

Berdasarkan hasil pengamatan peneliti di SD Negeri Muka Sungai Kuruk terhadap pembelajaran Agama Islam yang masih dirasa kurang optimal, hal ini dapat dilihat dari hasil belajar siswa dengan rata-rata 64,83 sedangkan KKM adalah 75. Hal itu terjadi karena sebagian siswa tidak memperhatikan saat pembelajaran. Pembelajaran masih bersifat teacher centered bukan student centered. Hal ini terlihat keaktifan siswa selama pembelajaran yang masih pasif, tingkat bertanya masih rendah, untuk berbuat kelompok masih kurang tanggap. Padahal jika dilihat faktor usia mereka, pada usia mereka anak-anak cendrung lebih aktif bergerak, berbicara dan berlari kesana kemari dalam melakukan sesuatu baik dalam proses pembelajaran dikelas. Akan tetapi selama pemantaua awal keaktifan siswa ini kurang terlihat.

Penerapan model pembelajaran yang belum optimal mengakibatkan siswa menjadi bosan. Siswa hanya diberikan buku teks pelajaran yang berisi bermacam-macam materi untuk 
dipelajari tanpa menggunakan metode dan model pembelajaran yang merangsang siswa aktif dan kreatif yang dapat menumbuhkan keterampilan untuk mengikuti pelajaran, terutama pada mata pelajaran Agama Islam yang cakupan materinya sangat luas. Pada materi Mengenal Malaikat Allah dan Tugas-tugasnya beberapa tahun sebelumnya selalu ditemukan kendala dikelas IV, biasanya siswa sering mengalami salah penyebutan, salah mencocokkan nama malaikat dan tugasnya. Hal tersebut terus terjadi tanpa ada perbaikan yang nyata dilakukan oleh guru mapel, apalagi materi tentang malaikat dan tugasnya sangat penting dalam agama islam sehingga siswa diharapkan tidak terjadi salah konsep terhadap materi tersebut. Dari permasalahan diatas, maka alternatif pemecahan yaitu dengan menerapkan suatu model pembelajaran yang dapat meningkat keaktifan dan hasil belajar siswa, salah satunya dengan menerapkan model make a match (mencari pasangan).

Dengan demikian melalui penerapan model Make a Match akan lebih mengaktifkan siswa dalam pembelajaran sehingga membuat pembelajaran lebih bermakna karena adanya keterlibatan siswa secara aktif selama proses pembelajaran berlangsung. Melalui Model ini, siswa juga akan terlatih untuk mengungkapkan gagasan, pendapat dan kritikan terhadap orang lain. Sehingga diharapkan mampu mengoptimalkan hasil belajar siswa.

Model pembelajaran make a match dikembangkan oleh Lorna Curron. Model ini dapat dilakukan dengan "cara siswa mencari pasangan sambil belajar mengenai suatu konsep atau topik dalam suasana yang menyenangkan. Model ini bisa digunakan dalam semua mata pelajaran dan untuk semua tingkatan siswa". (Isjoni, 2007:77).

Model pembelajaran make a match artinya model pembelajaran mencari pasangan. Setiap siswa mencari sebuah kartu (bisa soal atau jawaban), lalu secepatnya mencari pasangan yang sesuai dengan kartu yang ia pegang. Suasana pembelajaran dalam model pembelajaran make a match akan riuh, tetapi sangat asyik dan menyenangkan. make a match atau mencari pasangan soal/jawaban yang tepat, siswa yang sudah menemukan pasangannya sebelum batas waktu akan mendapat poin. Pasangan-pasangan yang sudah terbentuk wajib menunjukkan pertanyaan jawaban dan dibacakan di depan kelas.

Tekhnik mencari pasangan atau make a match merupakan model yang cukup menyenangkan yang digunakan untuk mengulang materi yang telah diberikan sebelumnya. Namun materi barupun tetap bisa diajarkan dengan model ini dengan catatan siswa diberi tugas mempelajari topik yang akan diajarkan terlebih dahulu, sehingga ketika masuk kelas siswa telah memiliki bekal pengetahuan. Permasalahan yang diformulasikan memiliki multi jawaban dan soal yang akan diberikan. Contoh penerapan model pembelajaran make a match dalam kegiatan pembelajaran adalah ketika pembelajaran berlangsung guru memberikan soal beserta pasangan jawabannya secara acak kepada siswa yang kemudian siswa mencari pasangan dari jawaban atau soal yang telah diberikan.

Kegiatan pembelajaran harus membawa siswa dalam mencari pasangan jawaban atau soal yang telah diberikan oleh guru. Penerapan model make a match dapat memupuk kerjasama siswa dalam menjawab pertanyaan dengan mencocokkan kartu yang ada ditangan siswa, proses pembelajaran lebih menarik dan nampak sebagian besar siswa lebih antusias mengikuti proses pembelajaran, dan keaktifan siswa tampak sekali pada saat mencari pasangan kartu.

Berdasarkan uraian diatas, bahwa model pembelajaran make a match merupakan model pembelajaran mencari pasangan dengan permainan kartu dalam mencari pasangan.

Setiap model pembelajaran memiliki langka-langkah dalam pelaksanaan, agar mudah diterapkan dalam pembelajaran. Menurut Komalasari, (2010:83-84), langkah-langkah penerapan model make a match adalah sebagai berikut:

1. Guru menyiapkan beberapa kartu yang berisi beberapa konsep atau topik yang cocok untuk sesi review, sebaliknya satu bagian kartu soal dan bagian lainnya kartu jawaban

2. Setiap siswa mendapat satu buah kartu

3. Tiap siswa memikirkan jawaban/soal dari kartu yang dipegang

4. Setiap siswa mencari pasangan yang mempunyai kartu yang cocok dengan kartunya (soal jawaban) 
5. Setiap siswa yang dapat mencocokkan kartunya sebelum batas waktu diberi poin

6. Setelah satu babak, kartu dikocok lagi agar tiap siswa mendapat kartu yang berbeda dari sebelumnya

7. Demikian seterusnya

8. Kesimpulan/penutup.

Adapun rumusan masalah dalam penelitian ini adalah:

a. Apakah dengan menerapkan Model Make a Match (Mencari Pasangan) dapat meningkatkan hasil belajar Pendidikan Agama Islam pada Materi Mengenal Malaikat Allah Dan Tugasnya bagi siswa kelas IV SD Negeri Muka Sungai Kuruk?

b. Apakah dengan menerapkan Model Make a Match (Mencari Pasangan) dapat meningkatkan keaktifan belajar Pendidikan Agama Islam pada Materi Mengenal Malaikat Allah Dan Tugasnya bagi siswa kelas IV SD Negeri Muka Sungai Kuruk?

\section{METODE PENELITIAN}

Jenis penelitian yang digunakan adalah penelitian tindakan kelas (Classroom Action Research) untuk meningkatkan keaktifan dan hasil belajar siswa melalui model Make a Match (Mencari Pasangan) pada materi Mengenal Malaikat Allah Dan Tugasnya. Subjek penelitian adalah siswa kelas IV yang berjumlah 30 siswa yang terdiri dari 16 siswa perempuan dan 14 siswa laki-laki dengan kemampuan akademik heterogen. Penelitian dilaksanakan di SD Negeri Muka Sungai Kuruk tahun pelajaran 2018/2019. Penelitian ini berlangsung selama \pm 3 bulan (Januari s.d. Maret 2019).

Penelitian tindakan kelas adalah upaya yang dilakukan guru dalam meningkatkan dan memperbaiki kualitas pembelajaran dengan melakukan perubahan-perubahan secara terencana dengan berkolaborasi atau partisipan dimana peneliti terlibat langsung secara penuh dalam proses penelitian dari awal sampai akhir. Penelitian tindakan kelas ini dilaksanakan dalam dua siklus, masing-masing siklus terdiri dari empat tahapan, yaitu: Perencanaan (planning), Pelaksanaan (action), Pengamatan (observing), Refleksi (reflecting) (Kemmis and Taggart: 1993).

Penelitian tindakan kelas harus dilakukan sekurang-kurang dua siklus tindakan yang berurutan. Informasi dari siklus yang terdahulu sangat menentukan bentuk siklus berikutnya. Oleh karena itu, siklus yang kedua, ketiga, dan seterusnya tidak dapat dirancang sebelum siklus pertama terjadi. Hasil refleksi harus digunakan sebagai bahan masukan untuk perencanaan siklus berikutnya Kunandar (2011).

Pada penelitian ini teknik pengumpulan data yang diperoleh dengan cara observasi yang dilakukan oleh peneliti dan guru mata pelajaran Pendidikan Agama Islam kelas rendah (Observer) untuk mengamati sikap siswa dalam berinteraksi selama proses pembelajaran dengan lembar pengamatan maupun dengan catatan lapangan yaitu catatan tertulis tentang apa yang didengar, dilihat, dan di alami oleh siswa dalam rangka pengumpulan data.

Selain teknik observasi, teknik tes juga digunakan untuk mengumpulkan data tentang hasil belajar pendidikan agama islam siswa setelah proses pembelajaran dikumpulkan dengan menggunakan ulangan harian. Ulangan harian dilaksanakan setelah dua kali pertemuan tatap muka (siklus 1) dan ulangan harian kedua dilaksanakan setelah dua kali pertemuan tatap muka (siklus 2). Tes hasil belajar pendidikan agama islam dilakukan pada siswa yang mengikuti pembelajaran kooperatif melalui model Make a Match (Mencari Pasangan).

Instrumen dalam penelitian ini tediri dari perangkat pembelajaran seperti : Silabus, Rencana Pelaksanaan Pembelajaran (RPP), Lembar tes tertulis, Lembar observasi. Pada penelitian ini terdapat teknik analisis data sebagai berikut: Data pengamatan, tes formatif dan observasi. 


\section{HASIL PENELITIAN DAN PEMBAHASAN}

Hasil pengamatan aktivitas belajar siswa pada penerapan Model Make a Match dalam upaya meningkatkan keaktifan dan hasil belajar siswa kelas IV SDN Muka Sungai Kuruk terlihat pada tabel berikut.

Tabel 1. Nilai Observasi Siklus I

\begin{tabular}{|l|c|c|c|}
\hline No & Aspek yang diamati & Jumlah Siswa & Persentase \\
\hline 1 & Siswa aktif mengikuti pembelajaran & 18 & $60,00 \%$ \\
\hline 2 & Siswa pasif mengikuti pembelajaran & 12 & $40,00 \%$ \\
\hline
\end{tabular}

Berdasarkan tabel tersebut diketahui, bahwa siswa yang aktif mengikuti pelajaran PAI sebanyak 18 orang atau sebesar $60,00 \%$, dan siswa yang tidak aktif adalah sebanyak 12 orang atau sebesar 40,00 \%. Pada siklu I pertama ini keaktifan siswa belum mencapai $\geq 75 \%$ sebagai bahan tolak ukur efektifitas pembelajaran pada Pendidikan Agama Islam.

Tabel 2. Nilai Hasil Belajar Siswa Pada Siklus I

\begin{tabular}{|l|l|c|c|c|}
\hline No & Aspek yang diamati & Jmlh Siswa & Persentase & Rata - Rata \\
\hline 1 & Ketuntasan belajar siswa & 19 & $63,33 \%$ & \multirow{2}{*}{$\mathbf{7 2 , 6 7}$} \\
\cline { 1 - 4 } 2 & Ketuntasan belajar siswa & 11 & $36,67 \%$ & \\
\cline { 1 - 3 }
\end{tabular}

Berdasarkan tabel tersebut di atas, bahwa siswa yang tuntas mengikuti pelajaran Pendidikan Agama Islam dan Budi Pekerti sebanyak 19 orang atau sebesar 63,33\% dan siswa yang tidak tuntas adalah sebanyak 11 orang atau sebesar 36,67\%. Sedangkan nilai rata-rata hasil tes pada siklus I sebesar 72, 67.

Aktivitas guru dan siswa selama proses pembelajaran bermuara pada hasil belajar siswa seperti ditunjukkan tabel 2. Nilai rata-rata siklus I dengan pembelajaran kooperatif melalui model Make a Macth pada materi Mengenal Malaikat Allah dan Tugas-Tugasnya belum memuaskan dengan rata-rata 72,67 dari ketuntasan secara individual dan ketuntasan belajar secara klasikal. Hal ini menunjukkan hasil belajar aspek kognitif pada siklus I dikatakan belum tuntas karena dari 30 siswa yang mencapai nilai kkm sebanyak 19 siswa sedangkan 11 siswa belum mencapai kkm 75 .

Untuk meningkatkan aspek-aspek yang masih kurang pada siklus I, maka berdasarkan hasil analisa observasi siswa, maka perlu adanya langkah-langkah perbaikan yang akan dilaksanakan dalam pembelajaran selanjutnya yakni melalui proses refleksi, diantaranya:

1. Penggunaan waktu yang telah dipersiapkan perlu diperhatikan sehingga langka-langkah pembelajaran yang telah didesain pada RPP dapat diimplementasikan pada saat berlangsung pembelajaran.

2. Belum terbiasa melaksanakan pembelajaran dengan model Make a Match (Mencari Pasangan), jadi siswa masih kebingungan pada awalnya

3. Sebelum dimulai pembelajaran guru lebih dahulu menekankan untuk sungguh-sungguh dalam mengikuti pembelajara

4. Guru perlu memberikan perhatian lebih kepada anggota kelompok yang cenderung individual, sehingga tidak terjadi dominasi 1 atau 2 siswa.

5. Guru perlu lebih memotivasi siswa yang cenderung pasif atau tidak serius, bercakap-cakap dan bahkan bermain-main dengan teman.

6. Untuk meningkatkan aktivitas belajar, maka semua siswa perlu kerjasama untuk menyelesaiakan tugas yang diberikan guru sehingga semua siswa dapat terlibat secara aktif dalam proses pembelajaran.

7. Guru perlu menyampaikan langkah-langkah pembelajaran dengan menggunakan model konstektual ceramah dan kerja kelompok

8. Guru perlu memberikan motivasi dan reward ( hadiah ) bagi yang aktif dalam kegiatan proses pembelajaran. 
Pada tindakan ini, pembelajaran dengan model Make a Match (mencari pasangan) ternyata belum mampu meningkatkan hasil belajar. Setelah dilakukan refleksi pada siklus I, maka disusun kembali skenario pembelajaran siklus II.

Tabel 3. Nilai Hasil Observasi Siklus II

\begin{tabular}{|l|l|c|c|}
\hline No & Aspek yang diamati & Jumlah Siswa & Persentase \\
\hline 1 & Siswa aktif mengikuti pembelajaran & 26 & $86,67 \%$ \\
\hline 2 & Siswa pasif mengikuti pembelajaran & 4 & $13,33 \%$ \\
\hline
\end{tabular}

Berdasarkan tabel 3 di atas, diketahui bahwa, siswa yang aktif mengikuti pelajaran Pendidikan Agama Islam sebanyak 26 orang atau sebesar 86,67 \% dan siswa yang tidak aktif adalah sebanyak 4 orang atau sebesar $13,33 \%$

Pada siklus II telah dilaksanakan pembelajaran dengan menggunakan model Make a Match (Mencari Pasangan). Aktifitas belajar siswa pada pelajaran Pendidikan Agama Islam mengalami peningkatan dibandingkan dengan siklus I. Jika dibandingkan dengan siklus I aktivitas meningkat dari 18 siswa atau sebesar 60,00\% meningkat menjadi 26 siswa atau sebesar $86,67 \%$ pada siklus II. Maka siswa yang aktif mengikuti pelajaran pada siklus II meningkat. Karena pada siklus II ini keaktifan siswa sudah melebihi dari persentasi ketuntasan minimul secara klasikal yaitu $75 \%$, maka tidak perlu lagi untuk melanjutkan pada siklus III.

Tabel 4. Nilai Hasil Belajar Siswa Pada siklus II.

\begin{tabular}{|l|l|c|c|c|}
\hline No & Aspek yang diamati & Jmlh Siswa & Persentase & Rata - Rata \\
\hline 1 & Ketuntasan belajar siswa & 27 & $90,00 \%$ & \multirow{2}{*}{$\mathbf{8 7 , 0 0}$} \\
\hline 2 & Ketuntasan belajar siswa & 3 & $10,00 \%$ & \\
\hline
\end{tabular}

Berdasarkan tabel 4 diatas, bahwa siswa yang tuntas mengikuti pelajaran Pendidikan Agama Islam sebanyak 27 orang atau sebesar 90,00 \% dan siswa yang tidak tuntas adalah sebanyak 3 orang atau sebesar $10,00 \%$, sedangkan nilai rata-rata hasil tes pada siklus II sebesar 87,00

Hasil belajar siswa mengalami peningkatan dibandingkan dengan siklus I. Jika dibandingkan dengan siklus I, siswa yang tuntas hanya 19 orang atau sebesar 63,33\%, menjadi 27 orang atau sebesar 90,00 \% pada siklus II. Rata-rata hasil tes belajar pada siklus I dari $72,67 \%$ menjadi $87,00 \%$ pada siklus II. Maka siswa yang tuntas meningkat pada siklus II. Karena pada siklus II ini ketuntasan siswa sudah melebihi dari ketuntasa minimul secara klasikal yaitu $\geq 75$, maka tidak perlu lagi untuk melanjutkan pada siklus III.

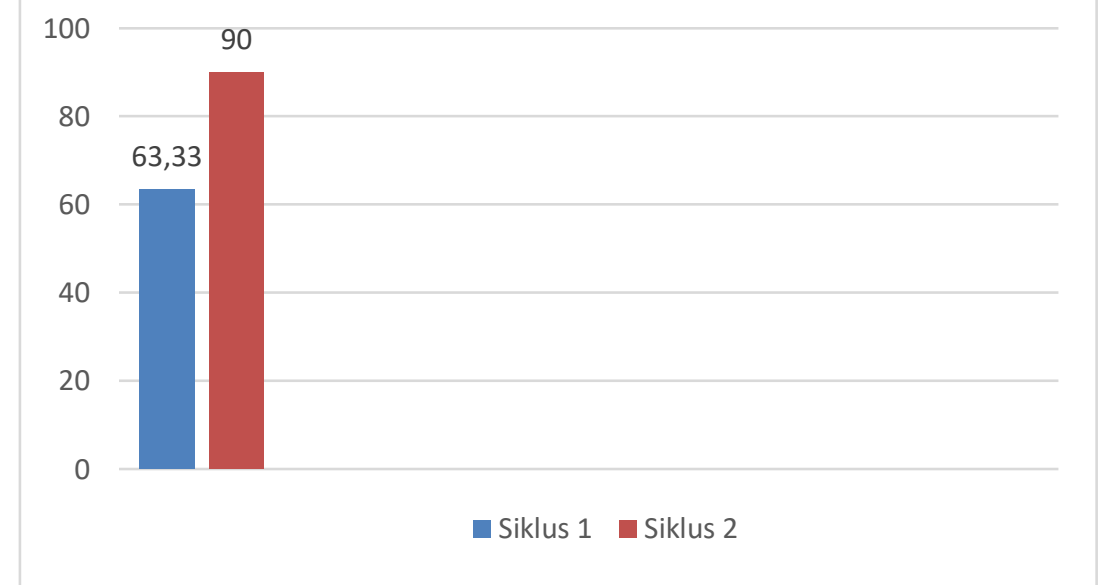

\section{Gambar 1. Grafik perbandingan persentase antara siklus I dan siklus II}

Dalam pelaksanaan Tindakan siklus II ada beberapa hal yang menjadi catatan yaitu :

1. Model Make a Match (Mencari Pasangan), siswa sudah memahami prosusdur kegiatan dan merasakan manfaatnya

2. Siswa termotifasi untuk menguasai materi pembelajaran;

3. Siswa antusias mengikuti permainan, 
4. Siswa sangat senang mencari pasangan kartu yang dipegang masing-masing siswa.

Adanya peningkatan keaktifan dan hasil belajar siswa selama proses belajar mengajar pada setiap siklus, menunjukkan bahwa model pembelajaran kooperatif dengan model Make a Match (Mencari Pasangan) sangat cocok di terapkan dalam kegiatan pembelajaran Pendidikan Agama Islam. Sebab selain keaktifan dan hasil belajar siswa meningkat, kekompakan serta kepercayaan diri.

\section{KESIMPULAN}

Berdasarkan hasil penelitian yang telah dipaparkan selama dua siklus, hasil seluruh pembahasan serta analisis yang telah dilakukan dapat disimpulkan sebagai berikut:

1. Model Make a Match (Mencari Pasangan) dapat meningkatkan hasil belajar siswa pada materi Mengenal Malaikat Allah dan Tugas-tugasnya bagi siswa kelas IV SD Negeri Muka Sungai Kuruk tahun pelajaran 2018-2019, yaitu pada siklus I siswa yang tuntas sebesar $63,33 \%$ menjadi $90,00 \%$ pada siklus II dari jumlah siswa 30 orang. Rata-rata hasil tes belajar pada siklus I dari 72,67 menjadi 87,00 pada siklus II.

2. Model Make a Match (Mencari Pasangan) dapat meningkatkan keaktifan belajar siswa pada materi Mengenal Malaikat Allah dan Tugas-tugasnya bagi siswa kelas IV SD Negeri Muka Sungai Kuruk tahun pelajaran 2018-2019, yaitu pada siklus I siswa yang aktif sebesar $60.00 \%$ atau sebanyak 18 orang, menjadi $86.67 \%$ atau sebanyak 26 orang pada siklus II.

\section{DAFTAR PUSTAKA}

Abu Ahmadi dan Joko Tri Prasetya. (2005). Strategi Belajar Mengajar untuk Fakultas Tarbiyah Komponen MKDK, Bandung: Pustaka Setia.

Djamarah S, Bahri \& Zain, Azwan. (2006). Strategi Belajar Mengajar. Jakarta: Rineka Cipta. Isjoni. (2007). Cooperative Learning Mengembangkan Kemampuan Belajar Berkelompok, Bandung: Alfabeta

Komalasari, Kokom. (2010). Pembelajaran Kontekstual. Bandung: PT. Rafika Aditama Komsiyah, I. (2012). Belajar dan pembelajaran. Yogyakarta: Teras

Kunandar. (2011). Langkah Mudah Penelitian Tindakan Kelas Sebagai Pengembangan Profesi Guru. Jakarta: Rajawali Pers.

Rusman. (2011). Model-Model Pembelajaran Mengembangkan Profesionalisme Guru, Jakarta: Rajawali Pers

Sugiyanto. (2010). Model-model pembelajaran Inovatif. Surabaya: Yuma Pustaka. Syaifurahman, \& Ujiati, T. (2013). Manajemen dalam pembelajaran. Jakarta: PT. Indeks. 